\title{
Bibliometric Analysis of Research on Moving Bed Biofilm Reactor
}

\author{
Laili Fitria $^{1^{*}}$, Dhuhan ${ }^{2}$ \\ ${ }^{1,2}$ Environmental Engineering Department, Engineering Faculty, Universitas Tanjungpura, Pontianak, \\ Indonesia \\ *Koresponden email: fitria.laili@gmail.com
}

Diterima: 29 Juli 2021

Disetujui: 6 Agustus 2021

\begin{abstract}
Waste discharged into the environment (air and water) should meet the expectations for environmental quality standards. A method that has been widely studied and to be used to maintain water quality is a combination of the Moving Bed Biofilm Reactor (MBBR) method. With the Dimensions database, during the last ten years (2010-2020), there have been 373 journals concerning the MBBR for wastewater treatment. Furthermore, a bibliometric analysis was performed with data from 2017 to 2020, using the Vosviewer visualization to determine the development of research on the MBBR. Indonesia is in 10th place and has authored five articles on MBBR. China, the United States, Iran, India, and Germany are some the other countries that conduct the most MBBR research. The journal with the most research on MBBR is Bioresource Technology. The author who has done the most research on MBBR is Olav Vadstein, by publishing four articles. Meanwhile, the institutions writing the most research about MBBR are the Norwegian University of Science and Technology and the Technical University of Denmark. Another combination of data-based systematic literature review (SLR) is required to complement the bibliometric analysis of the MBBR wastewater treatment study.
\end{abstract}

Keywords: bibliometric analysis, moving bed biofilm reactor, research trend, wastewater treatment, VOSviewer

\begin{abstract}
Abstrak
Limbah yang dibuang ke lingkungan (udara dan air) harus memenuhi baku mutu lingkungan. Salah satu metode yang telah banyak dipelajari dan dapat digunakan dalam menjaga kualitas air adalah pengolahan limbah menggunakan metode Moving Bed Biofilm Reactor (MBBR). Berdasarkan database Dimensions, dalam sepuluh tahun terakhir (2010-2020), diketahui ada 373 jurnal tentang MBBR untuk pengolahan air limbah. Selanjutnya dilakukan analisis bibliometrik dengan data tahun 2017 hingga 2020, menggunakan visualisasi dari Vosviewer untuk mengetahui perkembangan penelitian MBBR. Saat ini, Indonesia berada di peringkat 10, dengan lima artikel tentang MBBR. Sementara negara yang paling banyak melakukan penelitian tentang MBBR antara lain China, Amerika Serikat, Iran, India, dan Jerman. Jurnal yang paling banyak menerbitkan penelitian tentang MBBR adalah Bioresource Technology. Penulis yang paling banyak melakukan penelitian tentang MBBR adalah Olav Vadstein, dengan empat artikel. Sementara itu, institusi yang paling banyak menulis penelitian tentang MBBR adalah Norwegian University of Science and Technology dan Technical University of Denmark. Kombinasi lain dari tinjauan pustaka sistematis berbasis data (Systematic Literature Review) diperlukan untuk melengkapi analisis bibliometrik mengenai MBBR untuk pengolahan air limbah.
\end{abstract}

Kata kunci: analisis bibliometrik, moving bed biofilm reactor, pengolahan air limbah, trend riset, VOSviewer

\section{Introduction}

The Moving Bed Biofilm Reactor (MBBR) process is a biological wastewater treatment that aims to reduce the pollutant load in wastewater. This system was developed based on the concept of conventional biofilm processing. Microorganisms in biofilms are grown on sticky media in a processing reactor [1]. Moving bed biofilm reactor (MBBR) is a type of wastewater treatment process that Prof. Hallvard Ødegaard first discovered at the Norwegian University of Science and Technology in the late 1980s. Kaldnes Miljöteknologi commercialized the MBBR method. There are more than 700 municipal and industrial wastewater treatment systems installed in more than 50 countries. The MBBR system consists of an aeration tank similar to an activated sludge tank with a particular plastic carrier providing a surface on which the biofilm can grow. The carrier is made of a material with a density approaching the density of water $(1 \mathrm{~g} / \mathrm{cm} 3)$. An example is highdensity polyethylene (HDPE) with a density close to $0,95 \mathrm{~g} / \mathrm{cm} 3$ [2]. The MBBR method requires a sticky 
medium such as Kaldnes. Kaldnes has several types that are famous in the world, such as Kaldnes K1, Kaldnes K3, Kaldnes K5, and K7, while in Indonesia, the only types of Kaldnes are Kaldnes K1, Kaldnes K2, and Kaldnes K5.

The reduction of pollutant load on domestic wastewater by using the MBBR with Kaldnes K1 media (30\% filling media), the sampling time was carried out on $0,1,2$, 3rd, 4th, 5th, 6th, and seventh days had a processing efficiency of BOD levels on the seventh day was $83.3 \%$, while the efficiency of COD on the 7th day was $84.2 \%$ [3]. The efficiency of TSS on the 7th day was $90 \%$. Laundry waste processing using the MBBR method with Kaldnes K1 media (20\% filling media) can reduce the parameters of COD, BOD, Phosphate, and Surfactant [4]. The best reduction efficiency at 6, 8, and 10 days of observation is located on the 10th day of processing at $91 \%$ for BOD, COD efficiency by $93.81 \%$, phosphate efficiency by $86.10 \%$, and surfactant efficiency by $88.22 \%$. The treatment of laundry wastewater using the MBBR method with Kaldnes K5 media, processing BOD5, and COD levels is equal to 94.7 - 98.1\% for BOD5 and 86.9 - 94.35\% COD [5].

The search results for articles on MBBR use the keywords moving bed biofilm reactor, kaldnes, and wastewater. Regarding these keywords, the journals identified in Dimensions published between the 20102020 period totaled 373 journals. Research in search of this article aims to find out how the MBBR method is used for waste treatment based on bibliometric analysis. The data used for bibliometric analysis will be visualized with the Vosviewer application. VosViewer is a free computer program available for visualizing and exploring bibliometric knowledge maps. VOSviewer stands for Visualization of Similarities. The algorithm used in this program is almost the same as Multi-Dimensional Scaling (MDS). The clusters generated by VosViewer are automatically displayed in color on the map [6].

\section{Material and Methods}

In this study, the bibliometric analysis method consisted of two steps: selecting articles that are relevant to the theme and analysis of the articles. Data from Dimensions was exported on 27 July 2020 with the keywords Moving Bed Biofilm Reactor, Kaldnes, wastewater with full data.

\subsection{Selection of Relevant Articles and Proceedings}

The data used in this study is a collection of scientific publications regarding using the MBBR method, which comes from the Dimensions. All publications, along with ample contextual information - freely available for personal, non-commercial use. Access to the Dimensions data set is complete, comprehensive, and linked to data that includes publications, grants, patents, clinical trials, and policy documents.

Dimensions Analytics is used to meet the needs of academic institutions, government organizations, research funders, publishers, and R\&D departments. Dimension is an interactive portal that can be customized to showcase expertise and resources across agencies. As written by Thomas 2019, SLR is excellent to do before starting new research to study previous research as well as to find out the world's research trends in a particular topic.It is also able to identify other studies that are similar in that topic; and ensure the novelty of potential new research [7]. This research is expected to be able to identify the potential novelties of MBBR researchers in the future.

The type of publication used in this study is limited to articles published from 2010 to 2020. The first step is to limit the search criteria with the keywords "moving bed biofilm reactor, kaldnes, and wastewater." More than 7000 articles indexed in Dimensions were selected. Thus, the bibliometric analysis will be carried out from 2017 to 2020 . Furthermore, 181 articles were selected to be analyzed for visualisation.

\subsection{Article Analysis}

The next step is to analyze 181 selected articles based on author profiles, institutions, author's countries of origin, and text data from the tittle. Journals were selected to publish articles on "moving bed biofilm reactors, kaldnes, and wastewater" using VOSviewer software, also to link the groupings. Although there are many programs for analyzing text units and matrix similarities, VosViewer's strength lies in its visualization. The program's interactive options and functions make it easy to access and explore its bibliometric data networks, such as the number of citations or the co-occurrence relationship between key terms and concepts [8].

\section{Result and Discussion}

\subsection{Number of Articles Published Each Year}

The MBBR research mostly uses keywords: moving bed biofilm reactor, kaldnes, and wastewater. Regarding these keywords, the journals identified in the dimensions of the last ten years, namely from 2010 2020 , totaled 373 journals. Research on this topic decreased in 2013, amounting to 21 journals. However, it increased again until 2019 to reach 58 journals. To be applied to Vosviewer, only data from 2017 to 2020 will be taken. 


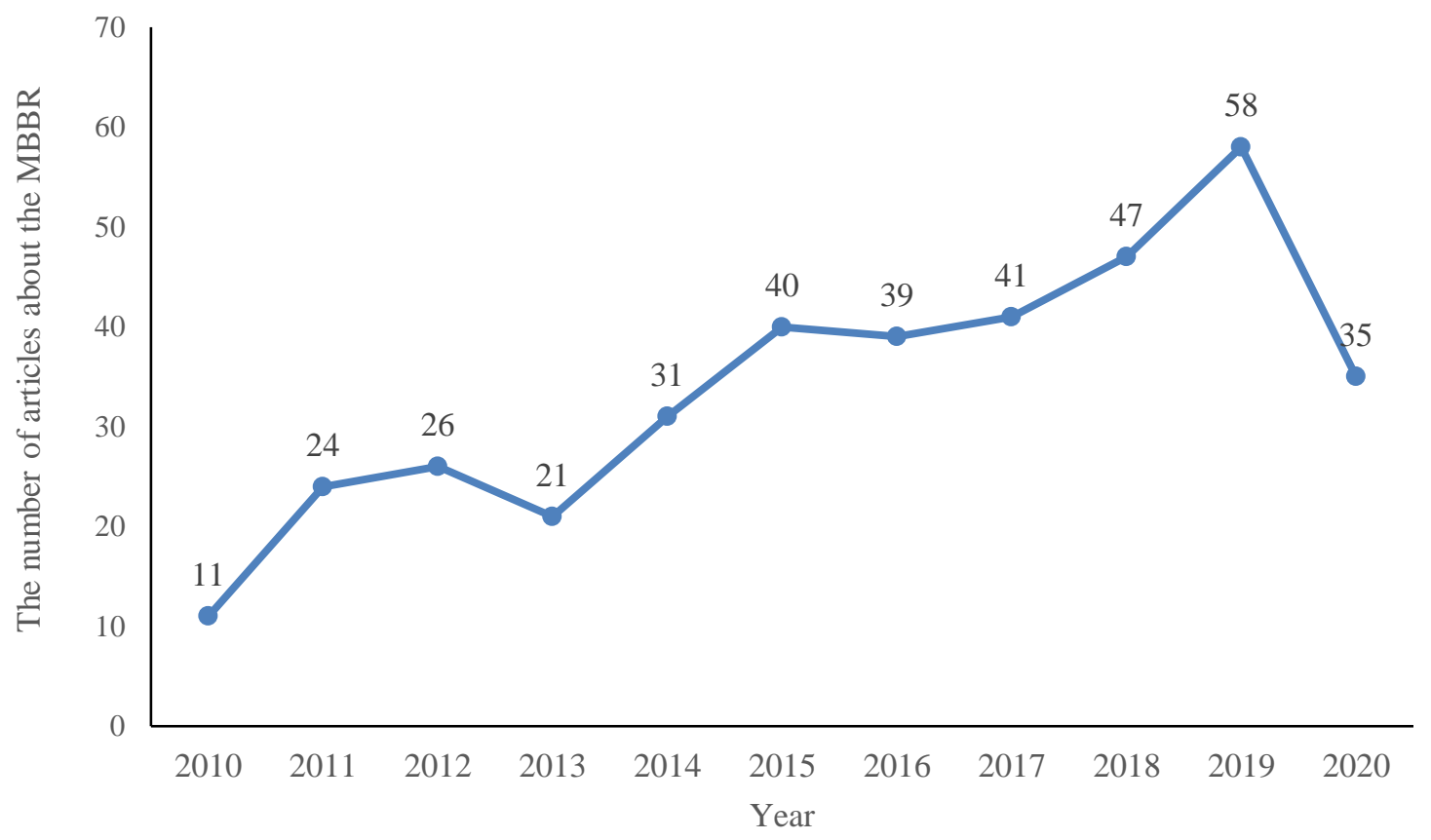

Fig. 1. Graph of the number of articles about MBBR from 2010 to 2020

From 2017 to 2020, 21 publishers issued a minimum of three journals on MBBR. Table 1 shows the ten publishers that issue a minimum of 3 journals, and it can be seen that the Bioresource Technology publisher is the publisher that releases the most significant number of journals in the last three years, amounting to 11 journal articles published. Table 1 is a list of 10 journal sources containing the most articles on MBBR, accompanied by the number of citations.

Table 1. Sources that have produced the most article about MBBR

\begin{tabular}{clcc}
\hline No & \multicolumn{1}{c}{ Journal } & Number of journal Articles & Citation \\
\hline 1. & Bioresource Technology & 11 & 10 \\
2. & Journal of Environmental Management & 10 & 8 \\
3. & Environmental Science and Pollution Research & 9 & 6 \\
4. & Water Science \& Technology & 8 & 6 \\
5. & Aquacultural Engineering & 7 & 7 \\
6. & Chemosphere & 7 & 2 \\
7. & The Science of The Total Environment & 7 & 10 \\
8. & Journal of Water Process Engineering & 5 & 4 \\
9. & Journal of Cleaner Production & 4 & 7 \\
10. & Water Research & 4 & 2 \\
\hline
\end{tabular}

From 2017 to 2020, there were 722 authors, but the were merely 13 authors who wrote more than three articles on MBBR. From Table 2, 10 authors published at least three journals, and it can be seen that the author Olav Vadstein wrote articles about MBBR as many as four articles. Olav Vadstein hails from Norway, the authoring institution of the Norwegian University of Science and Technology. Table 2 lists the ten authors who have the most articles about MBBR, accompanied by the number of articles. 
Table 2. Author name, author origin, and number of articles published

\begin{tabular}{|c|c|c|c|c|}
\hline No & Name & Institution & Country & $\begin{array}{l}\text { Number } \\
\text { of Article }\end{array}$ \\
\hline 1. & Vadstein, Olav & $\begin{array}{l}\text { Norwegian University of Science and } \\
\text { Technology }\end{array}$ & Norwegia & 4 \\
\hline 2. & Pedersen, Lars-Flemming & Technical University of Denmark & Denmark & 3 \\
\hline 3. & Pedersen, Per Bovbjerg & Technical University of Denmark & Denmark & 3 \\
\hline 4. & Bian, Wei & Beijing University of Technology & China & 3 \\
\hline 5. & $\mathrm{Li}$, Jun & Beijing University of Technology & China & 3 \\
\hline 6. & Zheng, Zhaoming & Beijing University of Technology & China & 3 \\
\hline 7. & Bassin, JoÃ£o Paulo & Federal University of Rio de Janeiro & Brazil & 3 \\
\hline 8. & Dezotti, MÃ & Federal University of Rio de Janeiro & Brazil & 3 \\
\hline 9. & Daigger, Glen T & University of Michigan & United States & 3 \\
\hline 10. & Delatolla, Robert & University of Ottawa & Kanada & 3 \\
\hline
\end{tabular}

\subsection{Author Contribution}

This section discusses the author, country of origin, author's institution, and the most cited articles. In Table 2, it can be seen that the author who has the most articles on MBBR from 2017 to 2020, namely Olav Vadstein from the Norwegian University of Science and Technology institution with a total of 4 articles. Then followed by Lars-Flemming, Per Bovbjerg, Wei Bian, Jun li, Zhaoming zheng, João Paulo, Márcia dezotti, Glen T Daigger, Robert Delatolla which has 3 articles.

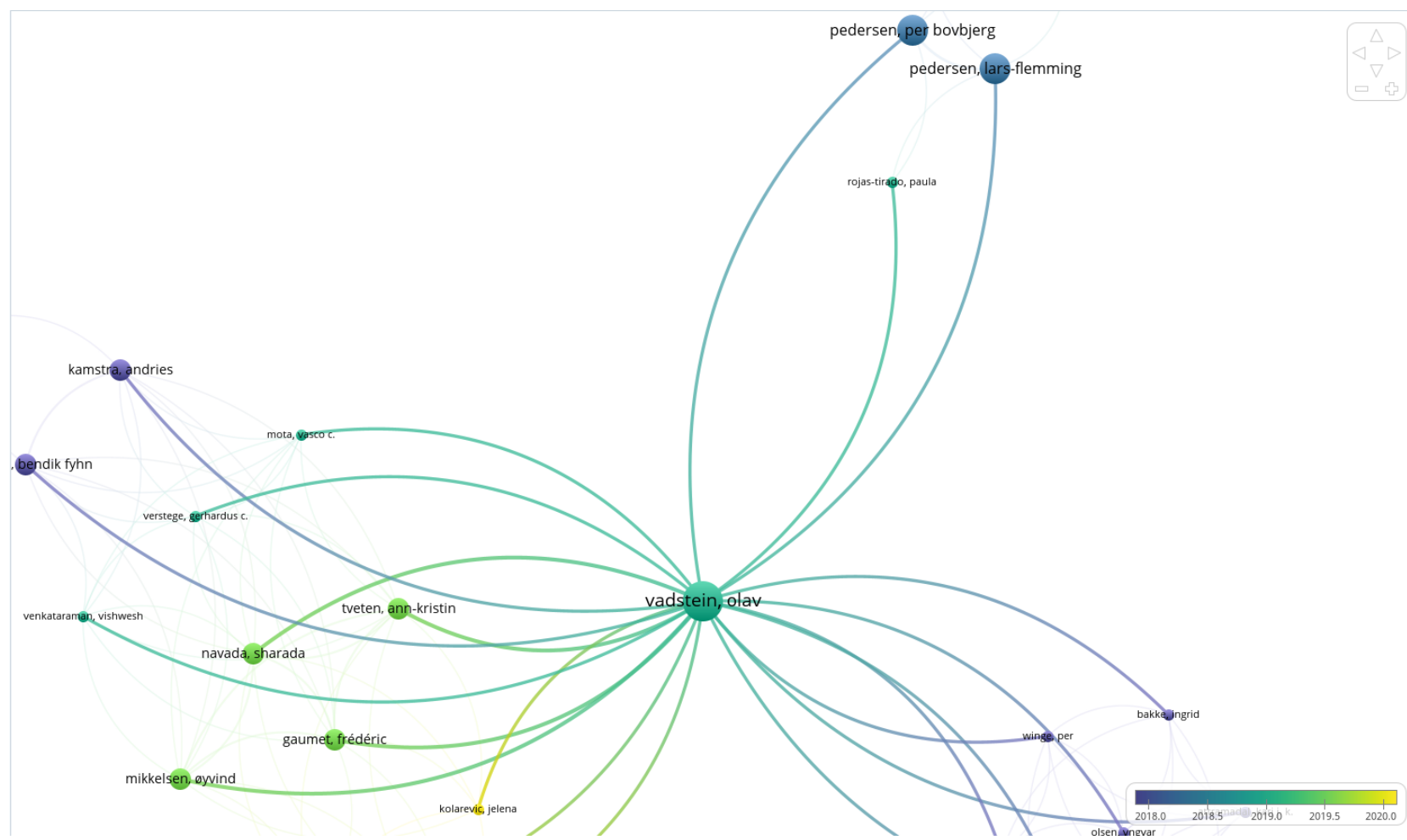

Fig. 2. Graph of co-authorship analysis by author-name [9]

From the VOSViewer analysis, it is known that 722 authors wrote about moving bed biofilm reactor (MBBR), and what is shown in picture 2 is the most extensive set consisting of 26 authors as the co-authored. There are four large clusters from the visual analysis, and Olav Vadstein is the author who writes the most together with other related researchers about MBBR. 


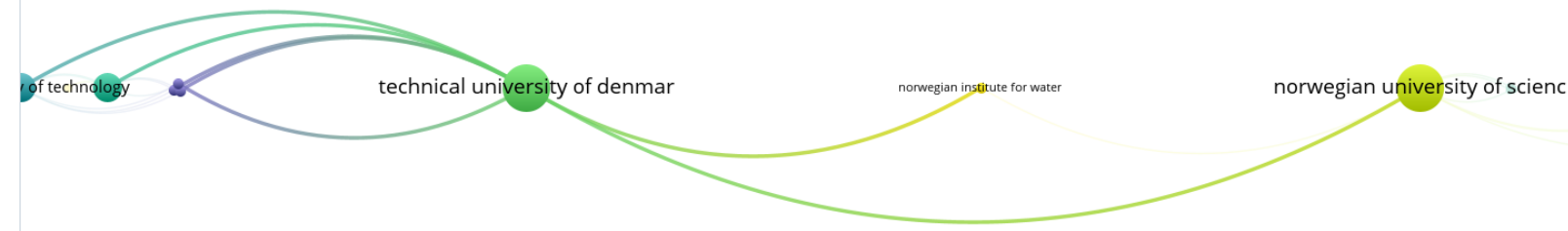

Fig. 3. Graph of co-authorship analysis by author organization [10]

There were 225 organizations issuing documents on the Moving bed biofilm reactor (MBBR), but the most giant set of related items was only 19 organizations divided into 5 clusters. The authors from the Norwegian University of Science and Technology and the Technical University of Denmark have both written five scientific articles from the picture.

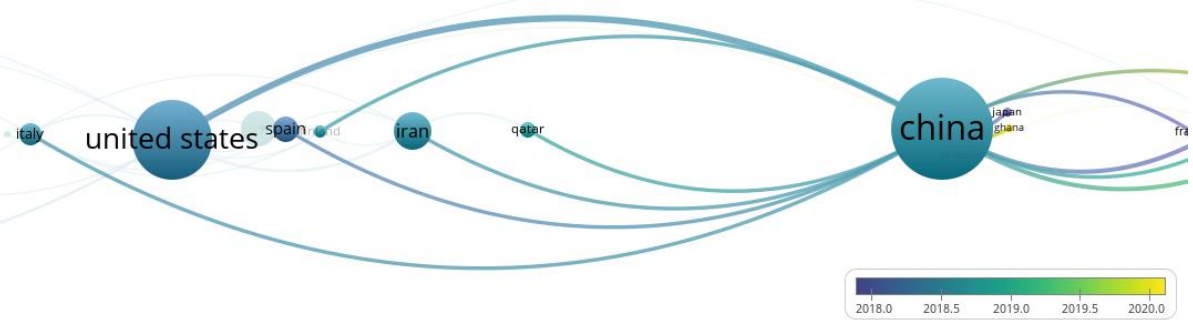

Fig. 4. Graph of co-authorship analysis by author country [11]

Based on the visual analysis, it is known that there are 44 countries of origin of authors who do coauthoring, but only 31 countries that have the greatest relationship. This relationship consists of 6 clusters, with China being the country of origin of the author who wrote the most on MBBR consisting 31 documents. Followed by the United States with 24 documents. There are also 11 MBBR documents written by researchers from Iran and India. ForIndonesia, there are five documents in which the authors wrote the MBBR article together with researchers from Australia, Malaysia, Pakistan.

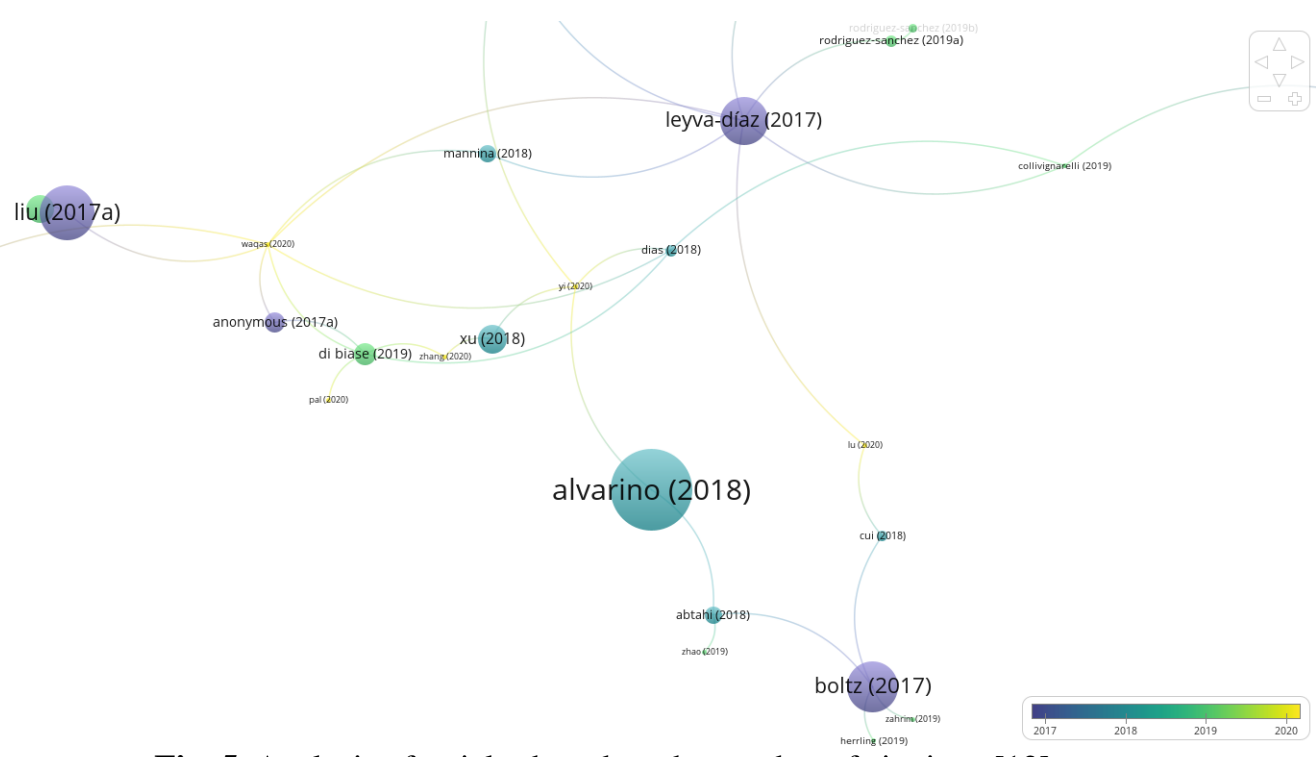

Fig. 5. Analysis of articles based on the number of citations [12]

From the VOSviewer analysis, it is also possible to find out which articles that have the most cited one. Of the 181 articles on MBBR, it is known that the largest group consists of 44 documents, which are divided 
into 11 clusters. In Figure 5, the most cited articles in the 2017-2020 period are articles from Alvarino (2018), which are quoted as many as 48 citations, with the title "Understanding the sorption and biotransformation of organic micropollutants in innovative biological wastewater treatment technologies" from the Journal: The Science of Total Environment. Table 3 shows the names of the documents with the most citations and the number of citations.

Table 3. The 10 most cited articles about MBBR

\begin{tabular}{|c|c|c|c|}
\hline No & Author (Year) & The Title & n Citation \\
\hline 1. & Alvarino (2018) & $\begin{array}{l}\text { Understanding the sorption and biotransformation of organic } \\
\text { micropollutants in innovative biological wastewater treatment } \\
\text { technologies [13] }\end{array}$ & 48 \\
\hline 2. & Liu (2017a) & $\begin{array}{l}\text { Upgrading of the symbiosis of nitrosomanas and anammox bacteria in } \\
\text { a novel single-stage partial nitritation-anammox system: nitrogen } \\
\text { removal potential and microbial characterization [14] }\end{array}$ & 32 \\
\hline 3. & Boltz (2017) & From biofilm ecology to reactors: a focused review [15] & 30 \\
\hline 4. & Leyva-diaz (2017) & Moving bed biofilm reactor to treat wastewater [16] & 28 \\
\hline 5. & Castro (2018) & $\begin{array}{l}\text { Treatment of a simulated textile wastewater containing the reactive } \\
\text { orange } 16 \text { azo dye by a combination of ozonation and moving-bed } \\
\text { biofilm reactor: evaluating the performance, toxicity, and oxidation by- } \\
\text { products [17] }\end{array}$ & 20 \\
\hline 6. & Sonwani (2019) & $\begin{array}{l}\text { A novel comparative study of modified carriers in moving bed biofilm } \\
\text { reactor for the treatment of wastewater: process optimization and } \\
\text { kinetic study [18] }\end{array}$ & 17 \\
\hline 7. & $\mathrm{Xu}(2018)$ & $\begin{array}{l}\text { Start-up of a full-scale snad-mbbr process for treating sludge digester } \\
\text { liquor [19] }\end{array}$ & 17 \\
\hline 8. & Zheng (2019) & $\begin{array}{l}\text { Enhanced nitrogen removal of the simultaneous partial nitrification, } \\
\text { anammox and denitrification (snad) biofilm reactor for treating } \\
\text { mainstream wastewater under low dissolved oxygen (DO) } \\
\text { concentration [20] }\end{array}$ & 16 \\
\hline 9. & Safwat (2018) & $\begin{array}{l}\text { Performance of moving bed biofilm reactor using effective } \\
\text { microorganisms [21] }\end{array}$ & 14 \\
\hline 10. & Di biase (2019) & $\begin{array}{l}\text { Moving bed biofilm reactor technology in municipal wastewater } \\
\text { treatment: a review [22] }\end{array}$ & 13 \\
\hline
\end{tabular}

\subsection{MBBR research development}

The text data analysis shows that most of MBBR research deals with reactors related to bacterium, optimization, and evaluation written in 2018. Meanwhile, in 2020, MBBR research leads to the theme of anaerobic-aerobic cycle effect, neural networks related to modeling and evaluation, bacterial enrichment, brackish water, biofilm characteristic, and biological nitrogen removal performance.

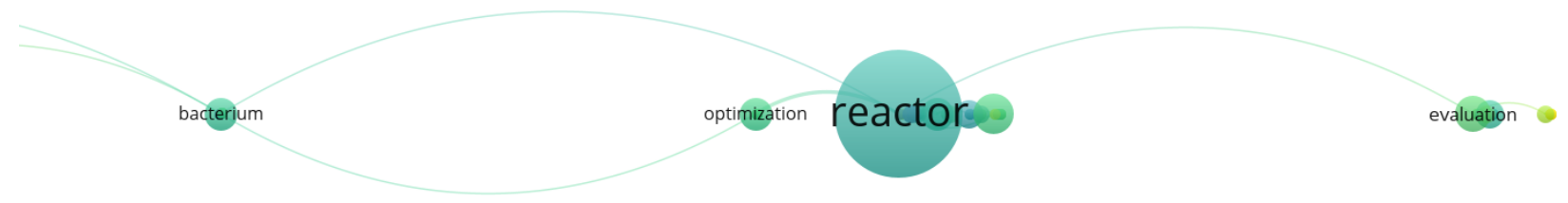

Fig. 6. Article analysis based on text data from the title [23]

\section{Conclusion}

The Moving Bed Biofilm Reactor (MBBR) research for wastewater treatment of journals identified in the dimensions from 2010-2020, amounted to 373 journals. Indonesia is ranked 10th and has issued five 
documents on MBBR from 2017 to 2020. The researcher who writes the most about MBBR is Olav Vadstein. The country that conducts the most MBBR research is China. The three publishers that publish the most MBBR articles are Bioresource Technology, Journal of Environmental Management, and Environmental Science and Pollution Research. The most-cited article on the MBBR is entitled Understanding the sorption and biotransformation of organic micropollutants in innovative biological wastewater treatment technologies. Combining other data-based systematic literature reviews (SLRs) is necessary to complement the bibliometric analysis of the MBBR research for wastewater treatment.

\section{References}

[1] I. Indriyati, "Pengolahan Limbah Cair Organik Secara Biologi Menggunakan Reaktor Anaerobik Lekat Diam," J. Air Indones., vol. 1, no. 3, pp. 340-343, 2018, doi: 10.29122/jai.v1i3.2361.

[2] A. van Haandel and J. van der Lubbe, Handbook of biological wastewater treatment. 2012.

[3] M. Al Kholif, "Penurunan Beban Pencemar Pada Limbah Domestik Dengan Menggunakan Moving Bed Biofilter Reaktor (Mbbr)," Al-Ard J. Tek. Lingkung., vol. 4, no. 1, pp. 1-8, 2018, doi: 10.29080/alard.v4i1.365.

[4] D. A. Kusuma, L. Fitria, and U. Kadaria, "Pengolahan Limbah Laundry Dengan Metode Moving Bed Biofilm Reactor (MBBR) (Laundry Wastewater Treatment Using Moving Bed Biofilm Reactor (MBBR) method)," J. Teknol. Lingkung. Lahan Basah, Jan. 2019, doi: 10.26418/jtllb.v7i1.31882.

[5] S. Bering, J. Mazur, K. Tarnowski, M. Janus, S. Mozia, and A. W. Morawski, "The application of moving bed bio-reactor (MBBR) in commercial laundry wastewater treatment," Sci. Total Environ., vol. 627, pp. 1638-1643, 2018, doi: 10.1016/j.scitotenv.2018.02.029.

[6] L. Leydesdorff and I. Rafols, "Interactive overlays: A new method for generating global journal maps from Web-of-Science data," J. Informetr., vol. 6, no. 2, pp. 318-332, 2012, doi: 10.1016/j.joi.2011.11.003.

[7] Y. Ulfa, D. E. Irawan, and B. Kombaitan, "Analisis Bibliometrik dari Penelitian Geologi untuk Tata Guna Lahan Perkotaan : 1950-2019,” 2019.

[8] N. J. van Eck and L. Waltman, "Citation-based clustering of publications using CitNetExplorer and VOSviewer," Scientometrics, vol. 111, no. 2, pp. 1053-1070, 2017, doi: 10.1007/s11192-017-2300-7.

[9] L. Fitria, "Graph of co-authorship analysis by author-name," VOSviewer, 2021. https://app.vosviewer.com/?json=https\%3A\%2F\%2Fdrive.google.com\%2Fuc\%3Fid\%3D109ecImr4X Z_NN5jW1MBJGE5spMpUz_eq (accessed Aug. 03, 2021).

[10] L. Fitria, "Graph of co-authorship analysis by author organization," VOSviewer, 2021. https://app.vosviewer.com/?json=https\%3A\%2F\%2Fdrive.google.com\%2Fuc\%3Fid\%3D1sMWWU mmikag85rFqagYMSOxut0QGjmK1 (accessed Aug. 03, 2021).

[11] L. Fitria, "Graph of co-authorship analysis by author country," VOSviewer, 2021. https://app.vosviewer.com/?json=https\%3A\%2F\%2Fdrive.google.com\%2Fuc\%3Fid\%3D1GBboc_GJ Pj0tkwvDivmyktHviLMTttXo (accessed Aug. 03, 2021).

[12] L. Fitria, "Analysis of articles based on the number of citations," VOSviewer, 2021. https://app.vosviewer.com/?json=https\%3A\%2F\%2Fdrive.google.com\%2Fuc\%3Fid\%3D16vuFzP8N ETTd2a1z719p7LOXR_OmQb5z (accessed Aug. 03, 2021).

[13] T. Alvarino, S. Suarez, J. Lema, and F. Omil, "Understanding the sorption and biotransformation of organic micropollutants in innovative biological wastewater treatment technologies," Sci. Total Environ., vol. 615, pp. 297-306, 2018, doi: 10.1016/j.scitotenv.2017.09.278.

[14] Y. Liu, "Upgrading of the symbiosis of Nitrosomanas and anammox bacteria in a novel single-stage partial nitritation-anammox system: Nitrogen removal potential and Microbial characterization," Bioresour. Technol., vol. 244, pp. 463-472, 2017, doi: 10.1016/j.biortech.2017.07.156.

[15] J. P. Boltz, B. F. Smets, B. E. Rittmann, M. C. M. Van Loosdrecht, E. Morgenroth, and G. T. Daigger, "From biofilm ecology to reactors: A focused review," Water Sci. Technol., vol. 75, no. 8, pp. 17531760, 2017, doi: 10.2166/wst.2017.061.

[16] J. C. Leyva-Díaz, J. Martín-Pascual, and J. M. Poyatos, "Moving bed biofilm reactor to treat wastewater," Int. J. Environ. Sci. Technol., vol. 14, no. 4, pp. 881-910, 2017, doi: 10.1007/s13762-0161169-y.

[17] F. D. Castro, J. P. Bassin, and M. Dezotti, "Treatment of a simulated textile wastewater containing the Reactive Orange 16 azo dye by a combination of ozonation and moving-bed biofilm reactor: evaluating the performance, toxicity, and oxidation by-products," Environ. Sci. Pollut. Res., vol. 24, no. 7, pp. 6307-6316, 2017, doi: 10.1007/s11356-016-7119-x. 
[18] R. K. Sonwani, G. Swain, B. S. Giri, R. S. Singh, and B. N. Rai, "A novel comparative study of modified carriers in moving bed biofilm reactor for the treatment of wastewater: Process optimization and kinetic study," Bioresour. Technol., vol. 281, no. January, pp. 335-342, 2019, doi: 10.1016/j.biortech.2019.02.121.

[19] X. Xu, G. Wang, L. Zhou, H. Yu, and F. Yang, "Start-up of a full-scale SNAD-MBBR process for treating sludge digester liquor," Chem. Eng. J., vol. 343, no. January, pp. 477-483, 2018, doi: 10.1016/j.cej.2018.03.032.

[20] Z. Zheng, "Enhanced nitrogen removal of the simultaneous partial nitrification, anammox and denitrification (SNAD) biofilm reactor for treating mainstream wastewater under low dissolved oxygen (DO) concentration," Bioresour. Technol., vol. 283, no. January, pp. 213-220, 2019, doi: 10.1016/j.biortech.2019.01.148.

[21] S. M. Safwat, "Performance of moving bed biofilm reactor using effective microorganisms," J. Clean. Prod., vol. 185, pp. 723-731, 2018, doi: 10.1016/j.jclepro.2018.03.041.

[22] A. di Biase, M. S. Kowalski, T. R. Devlin, and J. A. Oleszkiewicz, "Moving bed biofilm reactor technology in municipal wastewater treatment: A review," J. Environ. Manage., vol. 247, no. May, pp. 849-866, 2019, doi: 10.1016/j.jenvman.2019.06.053.

[23] L. Fitria, "Article analysis based on text data from the title," VOSviewer, 2021. https://app.vosviewer.com/?json=https\%3A\%2F\%2Fdrive.google.com\%2Fuc\%3Fid\%3D1OrJr_KKD huzTNNaFEYWiagh_R_0XHdT_(accessed Aug. 03, 2021). 